\title{
Application of Eco Industrial Concepts in Katunayalke Industrial Zone
}




\title{
Application of Eco Industrial Concepts in Katunayake Industrial Zone
}

\author{
Dissertation Submitted to the \\ University of Sri Jayewardenepura \\ as a Partial fulfillment for the \\ Requirement of the Final Examination of the \\ M.Sc. in Real Estate Management and Valuation \\ Degree
}

Full Nme

: Wijekoon Mudiyanselage Senaratne Wijekoon

Examination No. : REMV/60

Registration No. : GS/M.Sc/REMV/3412/08

Deaprtment

: Department of Real Estate Management

University

: University of Sri Jayewardenepura

Date of Submission : 18-03-2013 


\section{Student Declaration Page}

The work described in this dissertation was carried out under the supervision of Mrs. Nishani Wickramarachchi and any report on this has not been submitted in whole or in part to any university or any other institute for any other degree/examination or any other purpose. It is also certified that all the comments of the Viva voce evaluation have been incorporated in this final submission of the dissertation.

Full Name $\quad$ : Wijekoon Mudiyanselage Senaratne Wijekoon

Examination No : $\quad$ REMV/60

Signature

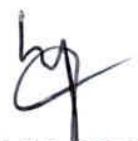

Date 27-05-2013 


\section{Supervisors Declaration}

Hereby, I certify that Mr.Wijekoon Mudiyanselage Senaratne Wijekoon ,Registration No. GS /M.Sc/REMV/3412/08 duly completed the research titled "Application of Eco Industrial Concepts in Katunayake Industrial Zone" under my supervision and recommended to submit for the evaluation.

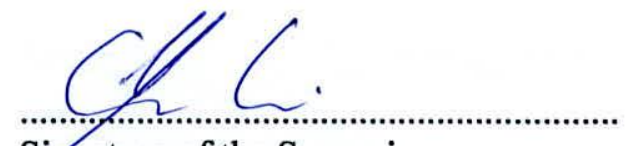

Signature of the Supervisor

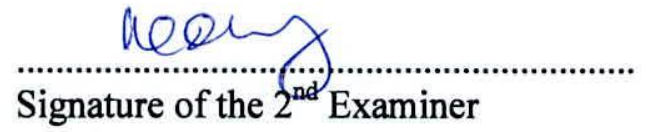

Signature and official stamp of the Head 


\begin{abstract}
Globalization, international competition and other post-war factors are the main roots of rapid industrialization of countries like Sri Lanka in late seventies.The country like Sri Lanka was in an unable situation, to absorb such rapid changes in the industry ,but had to accept it in order to overcome issues prevailed in its economy and face the consequences.
\end{abstract}

This rapid industrialization brought economic growth to Sri Lanka while creating many negative externalities due to the unpreparedness for these rapid changes. It is a strong belief among general public that the iindustrial areas are insinically dirty, dangerous, and polluting space, where proper approach is necessary to revert these impacts or to mitigate and control the negative externalities.

The Global actions towards mitigating thise conflicting situation are ofvaries from introducing EMS systems like ISO 14000, eco efficiency improvement tools etc, which needs investments where returns are not realistically predictable. Therefore actions to mitigate environmental effects alone will not encourage business community to take possible measures. Eco industrial actions which emphasize social, environmental and economical aspects in parallel will definitely be interested to all stake holders.

Introduction of EID concepts to this industrial estates will optimize the use of available resources, materials, infrastructure, and human capital to reduce costs, increase profits, and 1 reduce the release of harmful by-products to the environment. EID, by facilitating sustainable resource use will brings industrial space into a new light and fosters a better relationship between people and the environment.

This attempt is to create an awareness about potentiality of application of EID concepts among the stake holders and the research question identified as "how could efficiency of resource use be improved by introducing EID concepts in Katunayake Industrials zone. To answer this main question a main objective of this research is to identify the potential application of EID concepts to KIZ and finding net benefits and how stake holders may look at this imitative are the specific objectives.

The approach here is to select potential sample institutions and carry out a survey to collect data and quantify potential area of EID application and calculate net out come from such actions. As the second step in this research, these data were analyzed and presented to the stakeholders and their perception was measured. This stakeholder perception was identified as the industry readiness or the potential of applying EID strategies in the industrial sector.

Perception on EID was therefore measured by surveying and analyzing statistically, areas of decision making process identified as awareness, attitudes, and willingness to participate.

$\mathrm{KIZ}$ was selected as the case study as it has more concentrated set of industries with various disciplines and the combination or sharing of resources are high. 


\section{Acknowledgement}

My Sincere Gratitude goes to many people who supported me in completing this research work.

Firstly, my supervisor Ms.N.C.Wickramarachchi, Senior Lecturer, University of Sri Jayawardenepura, Sri Lanka who encouraged me, supported me and guided me throughout this process. Secondly to all my Lecturers of University of Sri Jayawadanepure, Sri Lanka including Prof.R.G.Ariyawansa, Prof.Henarath.Opatha, Prof.K.R.M.T .Karunaratne, Ms.Padma Weerakoon, Ms.Janaki Edirisinghe and Mr.S.N.Wijepala. My special thank goes to Mr. P.W Senaratne ,Our Valuation Lecturer and former Chief Valuer of Department of Valuation ,Sri Lanka, who taught me and created interest on the subject of Valuation.

I would specially mention the support given me by many student chapter members of the International society for Industrial Ecology by forwarding many literature and links to access to scholastic literature required to carry out this report and also for the ISIE for creating and supporting such a facility. Thank you all.

My Gratitude also goes to all staff members of the institutions of the Katunayake industrial zone including BOI, who helped me in collecting data and studying some of the processes in detail.

My grateful thank goes to all my batch mates who shared knowledge with me, spend many sleepless nights to fulfill our task of graduation, specially Jayasiri ,Hudson, Manamperi, Likson, who encourage me and helped me in numerous ways. If not I would have abandon this task.

Finally I would like to thank My wife Devika for tolerating my dedication to this study and encouraging me. And also to my departed parents for making me courageous enough to fight till the end. 


\section{Table of Contents}

Acknowledgement

Table of Contents

$-i$

List of tables

$-i i$

List of Figures

$-v i i$

Abbreviations

List of Annexes

Contents

CHAPTER ONE-Introduction

1.1. Back ground of the study

1.1.1. Industrial Estates and Environment

1.1.2. Environmental effects and mitigating actions

1.1.3. Introduction of EID concepts as mitigating actions

1.1.4. Operational inefficiencies observed

1.1.5. Barriers in introducing EIS concepts

1.1.6. Sri Lankan Perspective

1.2. Statement of the problem

1.2.1. Significance of the study

1.3. Objectives of The study

1.3.1. Main Objectives

$-16$

1.3.2. Specific Objectives

$-16$

1.4. Limitations

$-16$

1.5. Chapter Out line

\section{CHAPTER TWO-Literature Review}

2.1. Introduction

2.2. The Concept of Eco Industrial Development (EID)

2.2.1. Principles of Industrial ecology

2.2.2. Eco Industrial Development strategies

2.3. Barriers in Application of EID

2. 3.1. Technical Barriers

2.3.2. Regulatory Barriers

2.3.3. Economic Barriers 
2.4. Key positive elements in EID application

2.5. The Process of introducing EID

2.5.1. Implementation strategies in EID

2.6. Indicators of Eco Industrial initiative

2.6.1. Economic Indicators

2.6.2. Environmental Indicators

2.6.3. Social Indicators

2.7. Eco industrial development and Industrial parks

2.7.1. The nature of the Free Trade Zone

2.7.2. Historical perspective

2.7.3. Evolution of industrial estate in Sri Lanka

2.8. Literature on Application of EID

2.8.1. Quantifying Impacts

2.9. Importance of Stake holder participation

2.9.1. Identification of Stakeholders

2.9.2. Measurement of stakeholder perception

2.10. Grouping of Industry according to its activities

\section{Chapter Three- Research Methodology}

3.1. Introduction

3.2. Research Design

3.2.1. Research Model

3.3. Sample selection Methodology

3.3.1. Sample size selection

3.4. Data Collection methodology

3.4.1. Preliminary survey

3.4.2. Analysis of preliminary data

3.4.3. Data collection for first survey

3.4.4. Barriers in Application of EID actions

3.5. Stage 2 Survey (Finding Stakeholder perception) 
3.6.1. Introduction

3.6.2. Environmental \& Social Indicators $\quad-66$

3.6.3. Analysis of Industry readiness $\quad-70$

3.6.4. Hypothesis on stakeholder perception $\quad-71$

\section{Chapter Four-Case study area}

4.1. Introduction

4.1.1. Establishment of KIPZ

4.2. Board of Investment of Sri Lanka (BOI)

4.2.1. Objectives of BOI $\quad-74$

4.3. Physical aspects of KIPZ -76

4.3.1. Location of KIPZ -76

4.3.2. Availability of Infrastructure Facilities $\quad-77$

4.3.3. Distribution of Investor in country wise $\quad-79$

4.3.4. Distribution of Industry categories $\quad-79$

4.4. Economic Aspects of KIPZ $\quad-80$

4.5. Social aspects of KIPZ $\quad-81$

4.6. Environmental Aspects of KIPZ -82

4.6.1. Waste collection of KIPZ -83

4.6.2. Financial burden to BOI on managing environmental aspect $\quad-84$

4.7. Constrains faced By KIPZ

4.8. Application potential of EID Concepts $\quad-85$

4.9. Significance of KIZ as the case study area $\quad-85$

\section{Chapter Five -Data Analysis $\quad-86$}

5.1. Introduction $\quad-86$

5.2. Sample selection process for stage 1 survey $\quad-86$

5.2.1. Industry Classification $\quad-86$

$\begin{array}{ll}\text { 5.2.2. Sample distribution } & -87\end{array}$

$\begin{array}{ll}\text { 5.2.3. Attributes of selected samples } & -87\end{array}$

5.3. The Data Collection Process $\quad-90$

5.3.1. Data on Waste Generation $\quad-91$ 
5.3.2. Other data on Resources Input /Out Put $\quad-93$

5.4. Synergy matching Process $\quad-94$

5.4.1. Synergy -1(Cascading /Reuse of Waste water) $\quad-94$

5.4.2. Synergy -2(Co-generation of Standby power) $\quad-99$

5.4.3. Synergy-3 (Recycling of Plastic Waste) -105

5.4.4. Synergy-4 (Recycling of waste paper and corrugated packaging) $\quad-108$

5.4.5. Synergy -5 (Recycling of Waste Oils) $\quad-109$

5.4.6. Synergy -6 (Recycling/Reuse 0f waste wood) $\quad-111$

5.5. Evaluation of synergies in terms of social and environmental aspects $\quad-111$

5.5.1. Evaluation of synergies in terms of technical barriers -113

5.6. Joint provision of services $\quad-113$

5.7. The stage -2 survey (Stakeholder perception) $\quad-114$

5.7.1. Sample distribution -Stage 2 survey $\quad-114$

5.7.2. Data collection and tabulation $\quad-115$

5.7.3. Analysis of Stage 2. survey data $\quad-115$

5.8. Descriptive analysis of stage-2 data $\quad-116$

$\begin{array}{ll}\text { 5.9. Hypothesis testing } & -119\end{array}$

Chapter Six- Discussion \& Conclusion $\quad-122$

$\begin{array}{ll}\text { 6.1. Introduction } & -123\end{array}$

6.2. Viable Synergies identified $\quad-124$

$\begin{array}{ll}\text { 6,3.Discussion } & -126\end{array}$

$\begin{array}{ll}\text { 6.4. Recommendations } & -127\end{array}$

$\begin{array}{ll}\text { Bibliography } & -130\end{array}$

$\begin{array}{lr}\text { Annexes } & -133\end{array}$ 


\section{LIST OF TABLES}

Table1.1.Country forest cover change 1090-2000-Asia $\quad-12$

Table.2.1.Benifits of application of EID $\quad-34$

Table.3.1.Sample distribution as per industry category $\quad-55$

Tbale.3.2.Schedule of preliminary data collection $\quad-56$

Table.3.3.Data collection methodology-Stage-1 survey $\quad-38$

Table-3.4.Sample distribution-Sage- 2 survey $\quad-62$

Table 3.5.Data collection method-Stage-2 survey $\quad-63$

Table 3.6.Social cost /benefits indicator $\quad-67$

Table 3.7.Enviromental cost/benefit indicator $\quad-68$

Table 3.8.Combined analysis $-\mathrm{K} 2 \quad-68$

Table 4.1.Distribution of industrial zones as per administration authority $\quad-72$

Table 4.2.Chractoristics of industrial zones operated by BOI $\quad-74$

Table 4.3.Atributes of Katunayake Industrial Zone $\quad-75$

Table 4.4.Facilities provided by BOI in KIPZ $\quad-76$

Table 4.5.Leading institutions In KIPZ $\quad-77$

Table 4.6.Change in sectorial distribution of companies in KIPZ(1980-2003) $\quad-78$

Table 4.7.Share of zone Export values $\quad-78$

Table 4.8.Change in share of FDI In total investment to IPZ -A comparison $\quad-79$

Table 4.9.Anlysis of waste generated by all enterprises in KIPZ-Tons/Month $\quad-82$

Table5.1.Industry classification \& sample distribution $\quad-86$

Table.5.2.Attributes of selected sample institutions $\quad-86$

$\begin{array}{ll}\text { Table 5.3.Wood base industry category } & -87\end{array}$

Table 5.4.Paper based industry category $\quad-88$

Table 5.5Rubber \& Plastic industry category $\quad-88$

Table 5.6.Primary metal Industry category $\quad-88$

Table 5.7.Fabricated metal industry category $\quad-89$

Table 5.8.Industrial machinery \& equipments category $\quad-89$

Table 5.9.Electronic \& Electrical product category $\quad-89$

Table 5.10.Transport equipments category $\quad-90$

$\begin{array}{ll}\text { Table 5.11.Misalanous industry category } & -90\end{array}$

Table 5.12.Catagory of waste generation in KIPZ 
Table 5.13.Anlysis of water usage of sample institutions

Table 5.14.Cost benefit analysis of water synergy $\quad-97$

Table 5.15.Enviromental costs and benefits of water reuse -98

Table 5.16.Social costs and benefits $\quad-99$

Table 5.17.Energy consumption Data $\quad-101$

Table 5.18.Stand by power data $\quad-102$

Tbale5.19.Electricity power distribution losses $\quad-104$

Table 5.20.Environmetal cost and Benefits of sharing utility power $\quad-105$

Table 5.21.Social Cost and benefits of utility power sharing $\quad-105$

$\begin{array}{ll}\text { Table 5.22.Recycling of Plastics } & -106\end{array}$

Table5.23.By Product Input capacity -Sample $12 \quad-106$

$\begin{array}{ll}\text { Table 5.24.Cost benefit Analysis of Plastic material synergy } & -107\end{array}$

Table 5.25.Recycling of waste paper and corrugated packaging $\quad-109$

$\begin{array}{lr}\text { Table 5.26.Recycling of waste oil } & -110\end{array}$

Table 5.27.Cost benefits waste oil reuse/recirculation $\quad-111$

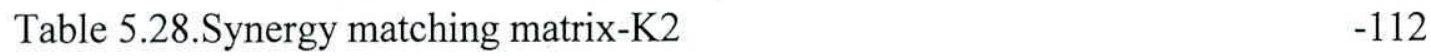

Table 5.29.Synrgy matching matrix -K1 (Evaluation of technical aspects) $\quad-113$

Table 5.30. Provision of services jointly. $\quad-114$

Table 5.31. Attributes of selected sample-stage -2 survey -115

Table 5.32.Supervisory and shop floor staff members perception $\quad-117$

Table 5.33.Participant's positive/negative perception on each criterion $\quad-118$

Table 5.34.Stage-2 survey- Final data on perception of stake holder $\quad-119$

$\begin{array}{ll}\text { Table.5.35.Stastical analysis of Directors perception } & -119\end{array}$

$\begin{array}{ll}\text { Table.5.36.Percepion of Managers } & -120\end{array}$

Table 5.37.Statistical analysis of perception of Managers $\quad-120$

$\begin{array}{ll}\text { Table 5.38.Perception of Supervisors of the zone } & -120\end{array}$

Table 5.39.Stasticl analysis of perception of Supervisors $\quad-121$

Table 5.40.Perception of Shop floor staff $\quad-121$

Table 5.41.Stastical analysis of perception of Shop floor staff $\quad-121$ 


\section{List of Figures}

Figure 1.1.Possible Environmental effects of Industrial estates $\quad-3$

Figure 1.2.Indictor of Human intervention on Environment

Figure 1.3.The Industrial Eco system $\quad-6$

Figure 1.4.Envirometal challenges $\quad-14$

Figure.1.5.Scarcity of fossil fuels $\quad-14$

$\begin{array}{ll}\text { Figure.2.1.Linear Industrial Process } & -18\end{array}$

Figure.2.2.Circular Industrial Model $\quad-18$

Figure.2.3.Sherwood plot-Material price vs. Dilution $\quad-28$

Figure.3.1.Conceptual Research Model $\quad-50$

Figure 3.2.Research Model

Figure.3.3.Reference Regional synergy model $\quad-51$

Figure 3.4.Sample Distribution Stage 2 survey $\quad-53$

Figure 3.5.Analysis process $\quad-66$

$\begin{array}{ll}\text { Figure.3.6.Synergy Grouping Chart } & -69\end{array}$

$\begin{array}{ll}\text { Figure.3.7.Synergy Matrix-K1 for Stage- 1survey } & -70\end{array}$

Figure.5.1.Catagories of Waste Generated in KIPZ -92

Figure 5.2.Waste Generation vs. Waste reuse in KIPZ -92

Figure 5.3.Distribution of No. of employees in sample firms -93

Figure 5.4.Intensity of Water use -93

Figure.5.5.Intensity of Energy use $\quad-94$

Figure.5.6. Industrial water use Vs. Waste water Generation $\quad-95$

Figure 5.7.Senario before Water Synergy -96

Figure 5.9.Senario after water synergy $\quad-99$

Figure.5.10.Energy Demand Vs Stand-by power availability $\quad-99$

$\begin{array}{ll}\text { Figure 5.11.Plastic material Loop } & -108\end{array}$

Figure 5.12.Sample distribution for stage 2 survey $\quad-115$

Figure 5.13.Director's perception on EID $\quad-116$

Figure 5.14.Manager's perception on EID $\quad-116$

$\begin{array}{ll}\text { Figure 5.15.Stake Holders positive perception } & -117\end{array}$

$\begin{array}{lr}\text { Figure 5.16.Stae holders negative perception } & -117\end{array}$ 


\title{
List of Annexure
}

Annex A-Location Map of KIPZ

Annex-B-Stage -2 Survey questionnaire

Annex-C-Chi Square table

Annex-D-DCF for Embedded power plant

Annex-E- Processed Data sample-stage-2 survey

\author{
Abbreviations \\ KIPZ-Katunayake Investment Promotion Zone \\ KIZ-Katunayake Industrial zone \\ EID- Eco Industrial Devlopment \\ EPZ-Export processing Zone \\ RIACs-Rapidly Developing Asian Countries \\ CEPT-Centralized Effluent Treatment Plant \\ BOI -Board of Investment, Sri Lanka \\ GCEC-Greater Colombo Economic Commission \\ N/H-Non Hazardous \\ DG-Distributed Generation \\ ISIC-International Standard Industry Classification
}




\section{CHAPTER ONE}

\section{Introduction}

\subsection{Background of the study}

The phenomenon of rapid industrialization was seen in most of the Asian countries such as, Thailand Singapore, Hong Kong and Korea in late sixties. This global trend of rapid industrialization flown in to Sri Lanka in late 70's with the opening up of its economy. The reasons behind this expansion of industrialization in to Asia were mainly due to new global trends like globalization, international competition and other post-war factors Chiu (2008).

Various measures are being adopted by governments in these countries to promote export competitiveness. As a policy means of achieving this goal, the concept of Export Processing Zone (EPZ) has gained noticeable significance in recent years. Terms such as Free Trade Zone (FTZs), Special Economic Zone (SEZs) and Investment Promotion Zone (IPZs) refers to similar concepts, with variations in policy prescriptions and objectives, offering free trade conditions and a liberal regulatory environment and duty concessions etc Sivanathan (2008).

To introduce such new industrial concepts, then Government of Sri Lanka introduced an institution called Greater Colombo Economic Commission (GCEC) .With the enactment of Act No 4 of 1978, foreign investments were flown in more freely and created a momentum in industrialization. More and more foreign investors moved to Sri Lanka to reap various advantages offered by the government.

The government's policy was focused mainly on the fulfillment of its social and political aspiration in the context of economic development only, and negative externalities to environment have not been properly considered in the planning stage. Therefore, these business firms moved to Sri Lanka as aliens to the society as well as to the business community itself. The coordination between these business entities and the society is very poor and most of the services and the materials they require are being imported using their duty free facilities. 